\title{
4. The Discourse and Practice of Precedence
}

\author{
James J. Fox
}

\section{Introduction}

Precedence refers both to forms of discourse and of practice. In considering precedence as an analytical category, it is appropriate to distinguish aspects of discourse and practice. However, in social analysis based on the use of precedence, it is the fusion of these aspects that gives credibility to the concept.

In this paper, I wish to begin by considering precedence as discourse, focusing on the kinds of relational categories that, applied recursively, provide coherence to forms of precedence. From this vantage, I would like to consider briefly how such discourse relates to practice in a number of different Austronesian-speaking societies. My selection of examples is intended not to cover anywhere near the full range of possibilities but rather, for the purposes of this paper, to highlight a number of contrastive forms. In particular, I am concerned to examine the difference between claims to precedence and claims to pre-eminence and how they relate to one another. Finally, I would like to outline a specific system of precedence, the status order of the domain of Termanu on the island of Roti, with particular attention given to claims to precedence and to pre-eminence by rival factions within its ambit.

\section{Precedence as Discourse}

As an analytic category, precedence defines an asymmetric relationship that may be extended recursively. Elsewhere (Fox 1989:44-48), I have defined the underlying features of precedence as 1) categorical asymmetry, 2) recursive complementarity, and 3) (the possibility of) category reversal. I should also note that precedence as a focus of concern often derives from a study of identities based on the investigation of origin structures.

Linguistically, precedence may be defined by any of a large and diverse class of lexical categories posed in an oppositional arrangement. I have referred to all such oppositional terms as 'operators'. What distinguishes these oppositional terms as operators is the fact that in discourse, one term of the pair is accorded a 'value' over the other. It is this imposition of a culturally defined value that gives an asymmetry to any particular opposition and to the relationship to which it applies. Thus, to give an example - of relevance to the case I present in this paper - the relative age categories, elder/younger, often serve as a common operator to define precedence in eastern Indonesia. In perhaps a majority of 
cases, elder is defined as superior to younger. The relationship of elder is given precedence over younger. The asymmetry of this relationship may be represented as Elder < Younger. There is nothing necessarily inherent in this asymmetry and, as comparative Austronesian ethnography makes abundantly clear even in cultures where this valorization is regarded as the norm, there are situations where this relationship may be reversed: Younger $>$ Elder. It is the possibility of such reversal that is critical to the discourse and practice of precedence. All lexical operators that are used to define precedence have this potential capacity and therefore may be said to function as 'lexical converses' (Cruse 1986:231-232).

Although a single relationship may be considered the limiting case, precedence may more generally be applied to an extended set of relationships. To define such relationships, it is essential that all operators, as complementary categories, have the capacity to be applied recursively to embrace an extended set of relationships. Thus, in the examples I have cited, the relative age categories, elder/younger, may indeed be applied recursively to include a wide number of individuals or groups.

For eighteenth century Maori society, for example, elder/younger categories were supposed to have included all members of a tribal group in a single all-embracing order (Metge 1967:21-24). This arrangement of precedence would be represented, in recursive notation, as follows: Elder $>$ Younger/Elder $>$ Younger... In this order of precedence, most individuals (or groups) are assumed to be involved in dual relationships that make them both younger to some and older to others. The claim to be first, foremost or pre-eminent in a line of precedence generally requires special 'grounding' and is invariably hedged with additional cultural explication.

In the study of precedence among Austronesian-speaking populations, it is rare to find an order of precedence that simply, unequivocally and undisputedly organizes a society. To the contrary, what occurs are a variety of categorical oppositions that pertain to different contexts, frequent contention over the application of competing oppositions, or over priority among multiple oppositions, and always the possibility of category reversal.

\section{Complementary categories in the discourse of precedence}

The distinction between elder and younger is a categorical opposition shared widely among Austronesian-speaking populations. As such it provides one of the most elementary 'operators' for the creation of precedence and is widely used in the assignment of status but it is not necessarily the most pertinent for social differentiation. The Paiwan in southern Taiwan, for example, are one society that lacks this categorical distinction. They have a single term, kaka, which applies to all siblings and cousins without distinction of age or gender. Lacking an elder/younger resource, the Paiwan stress the importance of the 'first 
born', either male or female. This person is known as the vusam, 'seed millet', and it is in relation to this vusam that a complex botanic idiom is elaborated. The first-born as 'seed millet' inherits the natal house and from this house 'gives seeds' (qumusam) to all younger siblings who are thus recognized as the 'seeds' (qusam) from that house. The house of the vusam is fixed in relation to other houses that derive from it. In the past, after the millet harvest, this botanic discourse was given explicit representation in the return of a bundle of millet to the vusam by each out-marrying, younger sibling. Thus a botanical discourse, an idea of derivation and a chain of succession among the Paiwan have the capacity to produce lines of precedence, which, over time, like lines of precedence in other societies, can become the subject of dispute, especially in claims to chiefdomship (see Matsuzawa 1989, Chiang 1993).

In a Paiwan village, all houses have names (ngadan) and are ordered in terms of (ritual) seniority. The chief of a Paiwan village can be regarded, in Chiang's words, as the 'vusam written large in the extra-familial context' (Chiang 2007). In Paiwan origin narratives, an order of arrival or appearance is translated into a sibling birth order: the first to arrive (or the first egg to open) becomes the first-born. This order also distinguishes nobles from commoners. But this discourse can also be overturned. Chiang contrasts the founding narratives of the Kuvulj and Durong villages with those of Parilaiyan and Talavatsal villages in which an outsider is first incorporated within the village by founding autochthonous houses but then usurps their position to establish its rule as chief. In some instances, the outsider and autochthon share complementary privileges (Chiang 2007; see Fox 2008 for a variety of Austronesian narratives of 'outsiders installed inside'). Thus even where a categorical opposition predominates, it can be reversed to produce a new line of precedence. This reversal can be socially specific to particular groups, as Chiang has indicated, serving to establish the predominance of a chiefly house in some (but by no means all) Paiwan villages.

In analysing the deployment of claims to precedence in various Austronesian-speaking societies, it is critical to distinguish the concept of precedence from that of hierarchy (Fox 1994). Whereas much discussion of precedence has focused on hierarchical relations (where precedence may cohere with, or even underpin, hierarchy), it is notable the claims of precedence can occur as well in relatively egalitarian societies as in societies with more stratified social formations.

In traditional kindred-based Iban society, for example, all individuals were considered equal (sebaka) and free to compete for power, prestige and wealth. The oppositional categories of elder and younger ( $\mathrm{k} k \mathrm{a} / \mathrm{adi}$ ) were a resource for possible differentiation but they were not determinative in accession to the bilik-household within a longhouse. Despite the emphasis on equality of relationships, there were clear notions of precedence among the Iban. As Freeman 
first noted (1981:31) and as Sather has described in greater detail (1996), much of the Iban discourse on precedence centred on the term, pun, whose literal meaning was 'trunk' or 'stem' but whose figurative meaning was that of 'source', 'basis', 'origin', or 'cause'. The term could be applied both to persons and to activities (see Fox 1995a for a discussion of the use of this 'trunk as origin' discourse in a variety of Austronesian-speaking societies; see also McWilliam in this volume).

According to Freeman, the root meaning of pun was 'that of stem, of a tree, from which the development of any activity springs' (Freeman 1981:31). Thus as Freeman explains, anyone could declare himself as an 'initiator' or 'leader' of a journey (bejalai) to gain wealth and recognition and if others chose to follow him, he would be considered the pun bejalai of the group. Similarly in other significant activities, such as launching of a raid or establishing a new longhouse, the initiator of the activity, if he managed to gather followers, would be considered that activity's pun and leader (tuai). The use of pun in such discourse focused on the formation of social followings, many of which were limited in time and scope but provided personal reknown. In Freeman's words, each 'individual had to be the source (pun) of his own achievements' (Freeman 1981: 350). For some, this offered a fleeting form of precedence but, for others, it became the basis of a continuing recognition.

The semantics of pun among the Iban also carries the implication of succession and continuity. Every longhouse community gave recognition to its founder who erected the first house pillar or 'trunk' (pemun > pun) and was known as its pun rumah or 'source'. Over time, there would be a succession of pun rumah, as indeed there was a succession of household source-figures (pun bilik) who assumed precedence in ritual and invariably had greater access to the longhouse as well as household land. The memory of their succession would figure in the main-line (pun tusut) of recited genealogies. Sather has noted the consequences of this discourse in Iban practice most clearly:

Recognition of this double meaning of pun, as both initiator and locus of continuity, helps illuminate the historical dynamics of Iban leadership. Thus in times of outward expansion, the Iban were able to throw up an array of effective leaders, who, as initiators of action and organizers of collective projects, led migrations, pioneered new areas of settlement, defeated rivals and competitors in war, felled jungle, and founded new longhouses and bilik-families. Those who were successful in these undertakings were, and continue to be, remembered, and so form the principal founders and connecting links in the main-line genealogies by which Iban remember and celebrate their ancestral past (Sather 1996:82).

More interesting still, in the analysis of precedence, are those societies where claims to precedence are couched in a metaphoric idiom that utilizes a variety 
of 'operators' whose layers of meaning can give rise to varied assertions and permutations in local practice. The more such oppositions are given credible valency, the more complex the contentions that can be generated over precedence. Thus while any one 'operator' — such as the distinction between elder/younger, or that between 'seed' and 'seeded' or 'trunk' and 'tip/branch' - offers a relatively simple means of differentiation, the multiplication of such operators offers fertile grounds for subtle distinctions and nuanced contention.

A good example is that of the Tanimbarese of Fordata Island in the southern Moluccas, which is clearly hierarchical with a hereditary class of nobles, commoners and (former) slaves but whose internal relations are ordered by a complex system of precedence. The Tanimbarese discourse on precedence uses a variety of idioms encountered elsewhere in eastern Indonesia, yet results, in practice, in a distinctive set of social arrangements. This discourse focuses heavily on the relationship between wife-givers and wife-takers. This relationship can be taken as a primary 'operator' which embodies an enduring linkage between 'brother' and 'sister'. As elsewhere in eastern Indonesia, wife-givers are considered as 'male' (brana) and wife-takers as 'female' (vata). Since wife-givers are regarded as superior to wife-takers, in the semantics of this relationship, brana has valency over vata: brana>vata. These categories are applied to houses (rahan) rather than to individuals.

To this discourse is added a botanic idiom of sources that combines with ideas about the transmission of blood. The house of the 'brother' as wife-giver is the 'source' (mata) of a 'sister' whose 'blood' (lara) carries the potential of life for his sister's children. These progeny are the 'sprouts' (mata/rubun) from his house (see Fox 1996 for similar relational conceptions in the Timor area). As the Tanimbarese assert, the purpose of a house is to 'multiply its sprouts a thousandfold' (see McKinnon 1991:111).

Another idiom in this rich discourse is drawn from the practice of sailing. The house of the brother is an anchored place of origin that launches boats that carry sisters to the houses of their husbands. The stability of this source insures the success of the journey and the return of valuables to the place of origin. In this context, male fixity stands in contrast to female mobility.

This discourse is utilized in the practice of a directed, asymmetric exchange of women between houses. Houses, however are themselves differentiated on the basis of an opposition between elder and younger. 'Elder' houses bear names (naran) and possess long-enduring affinal relationships; these extended relationships form what are called 'rows' (lolat). These 'rows' (and one's house's position within them) determine precedence. They form lines of precedence and pathways for the differential exchange of male and female goods based on long-standing alliance relations. By contrast with elder houses, younger houses have no names and their affinal relations extend for only a few generations. 
They are still in process of possible development. All marriages initiate a set of exchanges that continue for three generations and then conclude. If, however, marriage is renewed, this affinal line, known as a 'sister and aunt' pathway, takes on greater status and may 'feed' into a 'small row', thus establishing an initial position of precedence within the network.

'Rows' of affinally allied houses can be of varying length. Differentiation among 'rows' introduces the notion of relative size to this discourse on precedence. 'Small rows' (lolat ko'u) are said to 'feed' into 'big rows' (lolat dawan) and these 'big rows' can feed into the 'Great Row' (lolat ila'a) that 'anchors' the network of all exchange pathways. Strikingly, this 'Great Row', which links the four major houses of Fordata with the four major houses of the island of Sera, represents a reversal of the principle of asymmetric exchange on which all other 'rows' are predicated. Relations among the houses that comprise the 'Great Row' are symmetric - a double cycle of intermarriage in which all participating houses are considered of equal status. This 'Great Row' is considered to be a unity that transcends the opposition between brother and sister, male and female that underlies the other rows (see McKinnon 1991 and 1995 for a fuller account of this exceptionally rich social formation). ${ }^{1}$

While each of these sketches illustrates some of the basic possible workings of precedence, it is clear that the specifics of precedence in any one local social formation demand close, detailed examination. For this purpose, I examine one such case in more particular detail.

\section{Precedence and Pre-Eminence in the Domain of Termanu}

At this point, I would like to examine in detail a particular case of precedence based on reference to a set of oral narratives which claim to represent the establishment of precedence in one domain, Termanu, on the island of Roti in eastern Indonesia.

As a domain, Termanu (or Pada, as it is also known) represents itself as an assemblage of nine clans arrayed around a single noble 'origin' or 'trunk' group, known as Masa-Huk, that has grown and divided into two complementary but unequal clans, one male and one female. The male clan, which retains its designation as Masa-Huk, consists of a proliferation of ranked lineages surmounted by a royal lineage, Fola-Tein, that provides the ruling Male Lord (Manek) of the domain. The female clan, designated as Kota Deak, which means 'Outside the Fortification' retained its rights as lesser nobility but held only a minor political and ritual position.

Unlike other realms in eastern Indonesia (or even other domains on Roti where male and female clans preside over moiety groups), Termanu was, by long historical tradition, a markedly male-centred polity. Clans recognized by the 
Male Lord held a seat at his court and performed their 'origin' rituals ( $h u s$ ) either in relation to, or as lesser participants at, the great origin ritual of Masa-Huk.

The oral traditions that endeavour to account for the complex relationships within the domain are a diverse collection of chants, narratives, commentaries and genealogies, all of which are socially embedded in the individual traditions of separate clans. These traditions recount the founding of the domain, its coalescence and expansion, internal disputes among clan ancestors over critical resources, the transference of rule and the organization of precedence within the domain. Throughout these narratives, there occurs continuing comment on the nature of rule and on the role of cunning and cleverness in the achievement of pre-eminence.

Each individual narrative within this tradition is recognized as a true 'standing' tale (tutui-tete'ek) by its reference to specific named places within the domain and by its identification of actors in relation to named figures in the genealogy of the trunk group, Masa-Huk. Masa-Huk thus provides the focal genealogy without which no historical narrative can establish its position or its authenticity as a narrative of the domain.

The collection of oral chants and narratives pertaining to the domain of Termanu that I have (so far) collected come to more than a hundred pages of translated text. In this paper, I wish to examine the genealogy of Masa-Huk in relation to the particular narratives that establish the organization of precedence in the domain. I also wish to comment on the claims to precedence and pre-eminence that are either asserted or implied by these narratives. I begin with the genealogy of Masa-Huk. ${ }^{2}$

All genealogies on Roti are a recitation of names, each name consisting of two separate terms. Succession in a genealogy is achieved by the retention of the first term of a name as the second term in the succeeding name. Thus, in the recitation of the genealogy of Masa-Huk, Bui Putu is succeeded by Kilo Bui who is, in turn, succeeded by Kai Kilo.

To be understood properly, the genealogy of Masa-Huk must be conceived of not just as a temporal succession of names but also as spatial emergence from an earthly base. The first fifteen names of the genealogy chart a progression through three realms: from the earth through the seas to the heavens. Although not all names are intelligible or translatable, the recurrence of terms for earth (dae), for the sea (sain) and finally the term for the moon (bulan) imply this emergent process. The occurrence of the terms for stalk (putu) and tree (kai) are similarly evocative of a botanical emergence. Thus the genealogy begins with the name, Paki Dae, which might be translated as 'Earth Fastener' followed by $\mathrm{Hu}$ Paki-Paki, 'Base of Fastening' and then Dae Hu, 'Earth Base' and proceeds through such names as Sain Paliko, 'Sea Paliko' and Nggeo-Nggeo Sain, 'Darkness of (or on) the Sea' to the name, Bula Kai, 'Moon Tree'. 
It is important to note that Rotinese Christians who are concerned to reconcile this genealogy with the Biblical genealogy offer an exegesis on these names that identifies particular names as native equivalents of Old Testament names: hence Dae Hu is identified as Adam and Nggeo-Nggeo Sain as Noah. As a general point, it is essential to recognize the exegeses that accompany both narratives and genealogies. Even when there is agreement on the content of a genealogy or tale, there may be alternate interpretations of its meaning and significance and these varying interpretations can affect claims to precedence that may derive from it.

Figure 1. The first 15 names of the genealogy of Masa-Huk (represented as an 'upwards' progression from Paki Dae to Bula Kai. All genealogical recitations must begin with Paki Dae.

Bula Kai
Kai Kilo
Kilo Bui
Bui Putu
Putu Nggeo-Nggeo
Nggeo-Nggeo Sain
Sain Paliko
Paliko Damai-Do
Damai-Do Edok
Edo Ndesi
Ndesi Dae
Dae Hu
Hu Paki-Paki
Paki Dae

Only after these fifteen names, there occurs the first ancestral name, Ma Bulan, for whom there exists a full narrative. It is this narrative that provides the foundation of the domain.

This first narrative recounts the encounter of Ma Bulan with an 'autochthonous' figure named Pada Lalais. The names of both these ancestors are significant. Pada Lalais is represented as the first inhabitant of the island. $\mathrm{He}$ is intimately associated with the earth and is the ancestor of the clan that holds the ritual position of Head of the Earth (Dae Langak). Yet his name, which translates as 'Heavenly Pada', indicates a heavenly origin, which is asserted in the narrative.

As for Ma Bulan, although his name implies a heavenly origin, exegesis on this name interprets the term, Ma, as shortened form of Ana $\mathrm{Ma}(\mathrm{k})$, 'Orphan'. By this interpretation, Ma Bulan's name is 'Orphan Moon', thus suggesting some disjunction with a prior heavenly association. Ma Bulan is described as a wanderer, recently come from the sea, who encounters the settled Pada Lalais 
and immediately disputes his temporal priority and his rights to precedence. To determine precedence they agree to a contest.

The first contest involves the planting of trees to see which tree flourishes. Pada Lalais plants a quick growing damar tree whereas $\mathrm{Ma}$ Bulan plants a slow-growing bubuni tree, but after the trees are planted, Ma Bulan comes back and switches the trees and thereby claims a victory. Since Pada Lalais does not accept this outcome, they agree to a further contest.

This time, they vie with each other over who can command the sea to come. Since Ma Bulan knows the sea well since he is identified as a fisherman, whereas Pada Lalais only possesses a knowledge of the earth, Ma Bulan tells Pada Lalais to call the sea as the tide is going out. He calls but the tide recedes. Ma Bulan waits until the tide is about to come in; he then calls the sea and it comes to him, thus winning the second contest.

Finally the two agree to have a third contest by examining each other's houses to see which is the older one. Ma Bulan immediately rethatches his house with eucalyptus leaves and then lights a fire which quickly turns the thatch soot black. When they inspect each other's houses, Pada Lalais' lontar leaf thatch is not as black as the eucalyptus thatch of $\mathrm{Ma}$ Bulan's house. Ma Bulan once more claims victory.

In the end, Ma Bulan, who has demonstrated the cleverness required of a ruler offers the following solution to divide their functions. He says: 'It would be good if I became Lord and you became Head of the Earth for succeeding generations. When men have filled this domain, I will rule them and you may levy a tribute on the domain and take a portion of lontar syrup from each person who lives in the domain. And for all times, since you were the first to settle in this domain, this domain will be given the name Pada, in keeping with your name, Pada Lalais, and your grandchildren and descendants. ${ }^{3}$

Thus the domain is founded on a critical differentiation. The trunk line of Masa-Huk, via Ma Bulan, becomes the ruling line that is characterized as knowledgeable (malelak) and cunning (kekedi) while the line that begins with Pada Lalais becomes the ritual overseer of the earth that is characterized as dumb (nggoa) and ignorant of worldly wiles.

In Termanu, this division is complete and undisputed and has come to be represented as complementary division. In the traditional structure of the domain, the Head of the Earth represented by the clan, Meno, was given a place at court and thus fully incorporated into the domain. Elsewhere, however, in some of the domains of Roti, where a similar division between Ruler and Head of the Earth occurs, the enmity inherent in this division is stressed and narratives 
recount the attempts by the Head of the Earth to exterminate the ruling line. In some domains, the Ruler and the Head of the Earth could not be present together at any function.

Thus in Termanu, the fundamental division between Ruler and Head of the Earth is a muted source of dispute over precedence. Later differentiation within the line of Masa-Huk provides more immediate sources of dispute over precedence.

The recitation of genealogical names continues from Ma Bulan through six generations to Tola Manu without further significant differentiation. These names are listed as follows:

\section{Figure 2. The next seven names of the genealogy of Masa-Huk (recited 'upwards' from Ma Bulan to Tola Manu)}

Tola Manu
Manu Leki
Leki Kelu
Kelu Kila
Kila Muskanan
Muskanan Mak
Ma Bulan

The richest part of the narrative history of Termanu pertains to the figure of Tola Manu who is represented as the warrior founder of the domain, which then assumes his name (Tola Manu = Termanu) as well as that of Pada. Most of the ancestors of clans are incorporated into the domain during the reign of Tola Manu, either by conquest or by an alliance with Tola Manu. Only after the death of Tola Manu is there further differentiation in lines of precedence within Masa-Huk.

The next bifurcation is between the sons of Tola Manu: Seni Tola and Lusi Tola. The narrative of these two sons introduces another theme in the telling of the history of the domain. Whereas precedence is supposed to be accorded to the elder in a line of succession from elder to younger, this principle is inverted in the case of succession to the lordship of Termanu. Thus, among two brothers, the younger succeeds to rule; among several brothers, the youngest succeeds - if not immediately, eventually. While for Masa-Huk as a whole, the principle is either Elder < Younger or First-Born < Last-Born; for the royal line, this principle is reversed: Elder $>$ Younger or First-Born $>$ Last-Born.

In the narrative of the sons of Tola Manu, Lusi Tola is identified as the elder; Seni Tola as the younger. In exegesis, Seni Tola's name is referred, by folk etymological association, as 'Sengi' which means 'to win, to conquer, or to overcome'. This name is said to signify his triumph over his elder brother. Seni 
Tola's conquest follows the form of other narratives and thus involves a contest between the two brothers for which the 'Portuguese' serve as judges to determine the Ruler. The contest is to determine who is the heavier of the two brothers and thus the appropriate successor of Tola Manu. Seni Tola as the younger and lighter of the two brothers straps lead to a belt which is hidden by his sarong and is thus judged the heavier of the two. In Rotinese terms, he demonstrates that he is the more cunning of the two and therefore the more appropriate successor. His descendants continue the ruling line of Masa-Huk while those of Lusi Tola become the line of the Female Lord (Mane Feto or Fetor) and give rise to the clan, Kota Deak. The sign of the office of Male and Female Lord are staffs with either a gold or a silver capped-top. The Portuguese award the gold staff to Seni Tola and the silver staff to Lusi Tola.

The recitation of the genealogy of Masa-Huk continues. Just as the previous juncture produced a division between male and female clans, subsequent junctures in the genealogy produce the ranked lineages (teik) within the male clan, each of which forms a branch (ndanak) of the trunk, Masa-Huk. According to the genealogy and exegesis on it, Seni Tola had three sons. The youngest son, Kila Seni, succeeded to his father's position while the eldest son, Edo Seni, gave rise to the first of the noble clans of Masa-Huk, Hailiti-tein. (The second son, Bengu Seni, is said to have had no sons to succeed him.) In turn, Kila Seni is said to have had two sons, Pelo Kila and Sinlae Kila.

The genealogy of Lusi Tola within Kota Deak continues in parallel with that of the genealogy of Seni Tola in Masa-Huk. Lusi Tola is said to have had one son, Kiu Lusi, who in turn had two sons, Sadu Kiu and Ndoki Kiu. Following normal precedence, Sadu Kiu as the elder succeeded his father as the third Female Lord of Termanu.

The two parallel genealogies may be represented as follows:

Figure 3. The next three names in the genealogies of Masa-Huk and Kota Deak (recited 'upwards' from Tola Manu to Pelo Kila and Sadu Kiu)

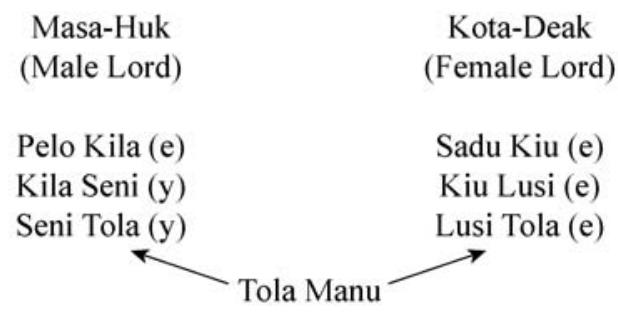

At this juncture, according to the narratives, Pelo Kila, the elder of the two sons of Kila Seni, succeeded to the position of Ruler while at the same time, Sadu Kiu, the elder son of Kiu Lusi, mounted a challenge and attempted to displace Pelo Kila in the order of precedence within the domain. 
Another contest ensued. In this contest, the 'Portuguese' were again called upon to test which of the two disputants' shit smelled sweetest. Sadu Kiu gave a feast to Pelo Kila who gorged himself while Sadu Kiu ate nothing but dilak fruit. As a consequence, Sadu Kiu's shit smelled sweeter and the gold-topped staff was given to Sadu Kiu and the silver-topped staff to Pelo Kila. But the narrative does not end with this reversal of fortune but continues to explain how 'cleverness conquers stupidity'.

In time, according to the narrative, Pelo Kila challenged Sadu Kiu on the grounds that he alone knew Malay and that he alone could deal with foreigners who came to Termanu. He accused Sadu Kiu of being a mere girl while he described himself as a 'real man' (tou manek, literally, 'a male man'). This play on words was intended to underline their true functions as Male and Female Lords of Termanu. Sadu Kiu relented and they exchanged staffs of office. The narrative ends with the comment that after a long reign Pelo Kila as elder brother surrendered his position to his younger brother, Sinlae Kila, who continued the ruling line of the domain. Pelo Kila established the branch lineage, Nelu-tein while Sinlae Kila continued the trunk line of Masa-Huk.

It is at this point that independent outside commentary based on Dutch archival sources can be brought to bear in a consideration of the oral narratives of Termanu. From the late 1670s, there are frequent references in these archives to Pelo Kila as 'regent' and Sadu Kiu as 'mede-regent' of Termanu. What is more, the General Missiven of the Dutch East India Company contain a short report that states that in 1679 the young regent Pelo Kila was taken to Kupang to learn Malay. By 1700, although Sadu Kiu continued as 'co-regent', Pelo Kila had been replaced by his brother, Sinlae Kila [in the Dutch records: Sinlay Kiera].

According to the genealogical narratives, a similar pattern was repeated in the following generation. Sinlae Kila had six sons: Ndaomanu Sinlae, Edo Sinlae, Kila Sinlae, Muloko Sinlae, Loe Sinlae and Fola Sinlae. Of these sons, the eldest, Ndaomanu Sinlae, (a figure of great prominence in Dutch archival records) was made Ruler but, after a disastrous attack on some Dutch officers, he was deposed and replaced by his youngest brother, Fola Sinlae. Each of the brothers, including Ndaomanu, became founders of separate lineages in Masa-Huk: Ndaomanu Sinlae established Ndaomanu-tein; Edo Sinlae, Edo-tein, Kila Sinlae, Kila-tein and Muloko Sinlae, Muloko-tein, and Loe Sinlae, Loe-tein.

In the next generation, Fola Sinlae was succeeded by his younger son, Muda Fola while his elder son, Muskanan Fola, became the founder of yet another lineage, that of Muskanan-tein.

As the genealogy of Masa-Huk proceeds, a process comes into play for which the Rotinese botanical image of a growing tree provides the most apt description. As the trunk continues to grow upward, branches formed at a lower level come to hold a lesser rank than branches formed at a later stage of development. This 
is the principle of apical demotion that underlines most Austronesian status lineage systems (see Fox 1995b:223ff). In Termanu, Pelo Kila is the ancestor of Nelu-tein. This lineage has a higher rank than Hailiti-tein which separated earlier from the main trunk of Masa-Huk. In turn, Nelu-tein has a lesser status than the lineages, such as Ndaomanu-tein or Kila-tein, formed in the next generation's branching. All these lineages in turn have lower status than that of Muskanan-tein of the next generation.

What is distinctive of Termanu is that elder lines are systematically demoted because the younger (or youngest) line in each generation represents the point of highest status. All of the lineages of Masa-Huk in the order of their separation form a line of precedence with its apex, the royal lineage of Fola-tein. This may be represented diagrammatically by the following figure:

\section{Figure 4. An illustration of the principle of apical demotion in which the younger (or youngest) is accorded precedence}
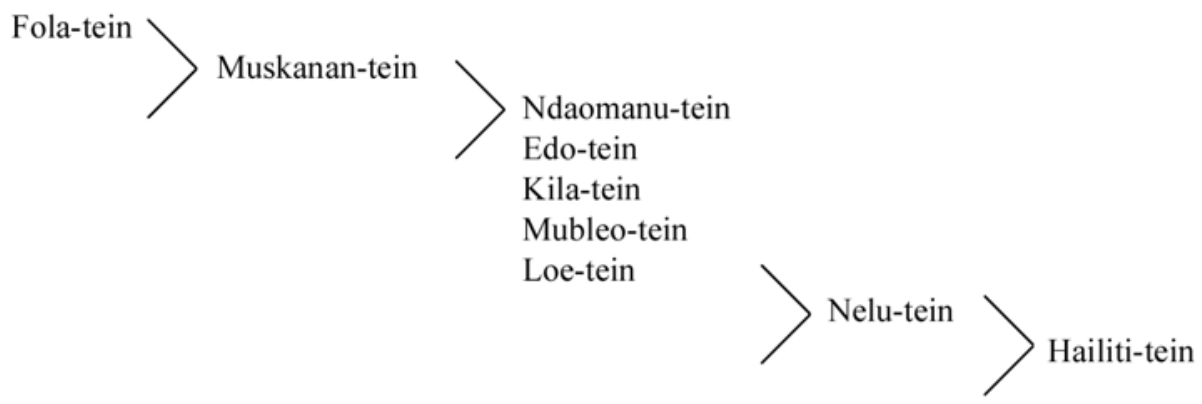

In the generation of Fola Sinlae, five branch lineages are said to derive from the trunk, Masa-Huk. Since this multiple branching process occurred in the same generation, among several brothers, the relative status of these lineages is a contentious subject. While the youngest brother's pre-eminent status is not disputed, the status of the other brothers is ambiguous. There is no clear ordering rule.

The normal status principle would assign precedence to the eldest but, in the noble traditions of Termanu, it is possible for the next 'youngest' - the brother closest to Fola Sinlae - to claim the next highest status. However, in Roti, only the position of first and last-born child are categorically distinguished. All other children occur in the 'middle'. Hence special claims among the 'middle' brothers are difficult to sustain. Other criteria are necessary to support claims to precedence, the most prominent of which is the claim to have continued to marry with the royal line. 
Figure 5. Lines of precedence in Masa-Huk

Ancestral Names

Clans and Lineages

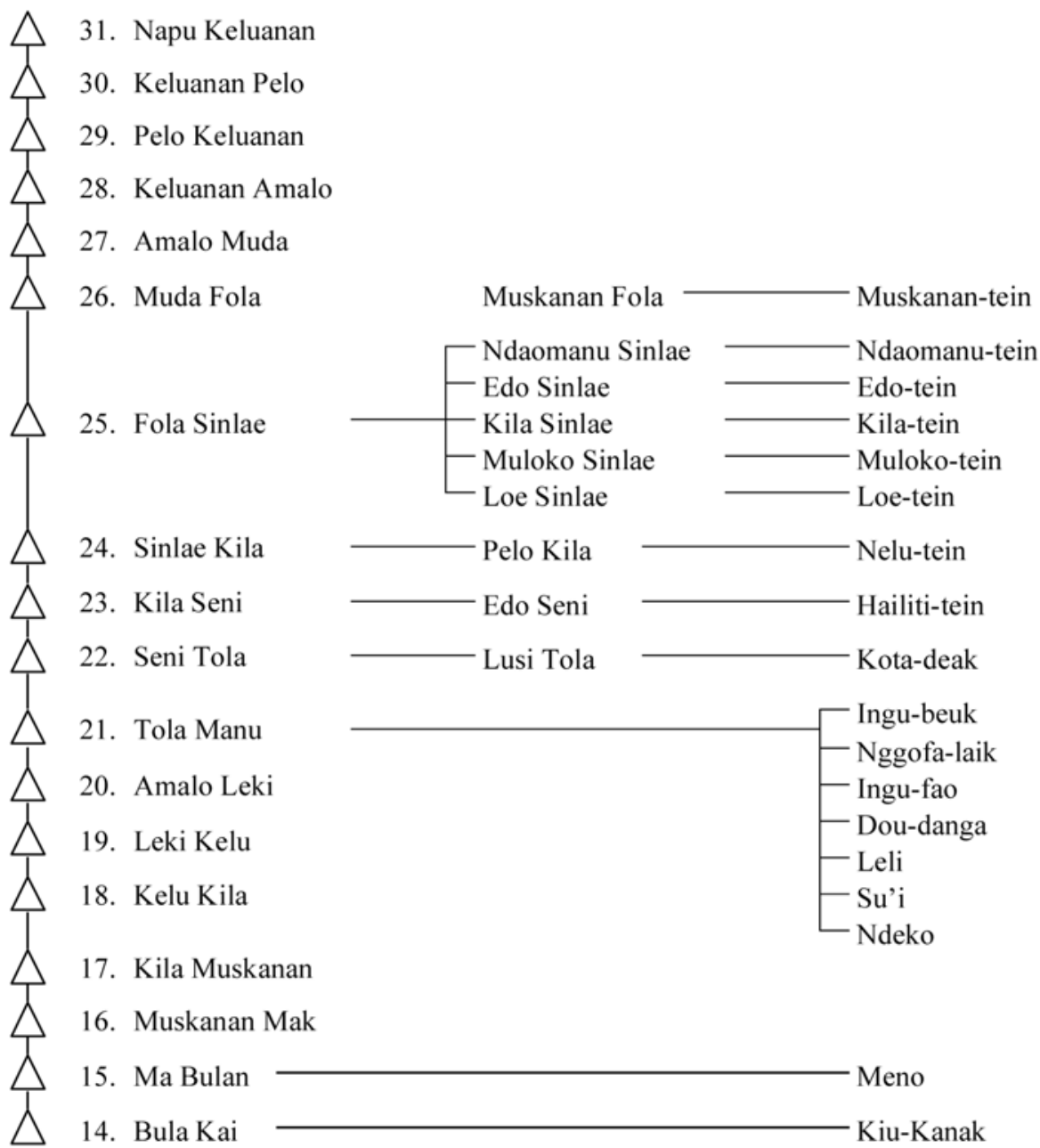

E. Douglas Lewis (1996:163-168) has devoted careful attention to the branching structures that create lines of precedence among the Tana 'Ai and he makes the fundamental observation that there is a difference between lines of precedence based on branches that bifurcate creating two new entities and those in which one line creates a bifurcation while the other maintains what is considered to be the main trunk line.

Termanu presents an interesting case in this regard. Fola-tein is recognized as a distinct lineage; at the same time, it is recognized as the pre-eminent continuer of Masa-Huk. It is my suspicion that as long as the rituals of Masa-Huk were performed, Fola-tein's position was emphatically that of the 'trunk' but 
with the abandonment of 'ceremonies of origin' (hus), Fola-tein's position, without its ritual underpinnings, has come to be regarded as the foremost branch lineage among a group of status lineages.

Relative derivation within Masa-Huk is not the only criterion of status. Marriage with Fola-tein (or with any lineage of higher derivation) is also a criterion and indeed evidence of the capacity to retain status. While relations of derivation are phrased in terms of elder/younger, relations based on marriage are phrased in terms of the gender categories, mane/feto, which translate both as male/female and brother/sister.

To maintain their position of pre-eminence, the rulers of Termanu have consistently married royal women of other domains. For all other lines within Fola-tein and within all the status lineages of Masa-Huk, past marriages have created a complex network of relationships on which to claim status. Only Muskanan-tein has succeeded in retaining its relative rank. For all the other lineages, the picture is less clear-cut and made even more complex by the rise to high status of a powerful client line within Fola-tein itself. Although it is impossible here to sketch this complexity, it is important to note that arguments over precedence generally focus more on marriage relations among the status lineages rather than on relations of derivation which are commonly agreed upon and thus tend not to be disputed.

Thus two different ways of reckoning precedence - one by derivation and the other by progenitor relations - provide the contentious basis for claims to status in Termanu.

\section{Concluding Comment}

It is appropriate here to emphasize that the application of the concept of precedence in the study of indigenous ideas of origin is still in its early stages. Although it clearly provides valuable insights, it also prompts further questions for consideration, which in turn may allow us to refine and develop the concept itself.

As illustration, I provide one example. In this paper, I have focused on the recursive application of certain asymmetric oppositions in the construction of precedence. It is also possible, it would appear, to construct relations of precedence on the basis of lexical triplets. Tom Therik in his study of Wehali on Timor notes a set of such relationships (Therik 2004). This set consists of the categories: Reclining $>$ Sitting $>$ Standing which are also given physical expression in ritual interactions. Thus, among the Wehali, the pre-eminent ritual figure is that of the Maromak Oan, who is defined as the 'reclining' lord.

While this set may be regarded as composed of dyadic sub-sets, the set as a whole is more than these oppositions. The set is asymmetric but instead of being recursive, it is fixed and stable. With this example in mind, it is reasonable to 
look for other ethnographic examples of such triplet sets and to compare the way they function in organizing relations of precedence.

It is also worth noting that the concept of precedence offers one mode of apprehending Austronesian societies. It is a means of apprehending and understanding formal relations in Austronesian societies. There are, however, many Austronesian societies where formal relations are themselves implicitly, and often explicitly, left undeveloped in favour of individuality and autonomy. Thus, among the Iban, as described by Sather (1996), relations of precedence may be individually imagined and even enacted at each gawai performance; such precedence is left to continuous individual reformulation.

The metaphor of the 'path' is a recurrent Austronesian trope. Often it is used to describe recognized lines of precedence within a society but just as often in other societies, it describes a trajectory toward the individual achievement of power, prestige, and renown. From a comparative perspective, those societies that place great emphasis on individual autonomy and independence are generally characterized by what I have elsewhere described as systems of lateral expansion (Fox 1995b:222-225). Such systems occur, or have tended to occur, in conditions, such as unrestricted horticulture, shifting cultivation or boat nomadism, that place few limitations on the formation of new groups. As restrictions begin to occur, patterns of precedence also begin to emerge. Such patterns take many forms. One such pattern, for example, which is to be found in eastern Indonesia is what might be called 'seasonal precedence' in which a period of the year is marked out for the performance of rituals that are organized according to rules of precedence, after which individuals disperse to scattered fields where relations of precedence rarely impinge on daily life. In such societies, precedence is concentrated within a temporal modality.

The concept of precedence may thus be called upon as an analytic category for ethnographic description but also as a comparative index of social transformations within the Austronesian-speaking world. 


\section{References}

Chiang, Bien

1993 House and social hierarchy of the Paiwan. Unpublished PhD thesis. Philadelphia: University of Pennsylvania.

2007 Articulation of hierarchies: house, community and value among the Paiwan. Unpublished paper presented at a Taiwan seminar (29 October 2007) in the Department of Anthropology, Research School of Pacific and Asian Studies, The Australian National University, Canberra.

Cruse, D.A.

1986 Lexical semantics. Cambridge: Cambridge University Press.

Fox, James J.

1971 A Rotinese dynastic genealogy: structure and event. In T.O. Beidelman (ed.), The translation of culture, pp.37-77. London: Tavistock.

1989 Category and complement: binary ideologies and the organization of dualism in eastern Indonesia. In David Maybury-Lewis and Uri Almagor (eds), The attraction of opposites: thought and society in a dualistic mode, pp.33-56. Ann Arbor: University of Michigan Press.

1994 Reflections on 'hierarchy' and 'precedence'. In M. Jolly and M. Mosko (eds), Transformations of hierarchy: structure, history and horizon in the Austronesian world. History and Anthropology (Special Issue) 7:87-108.

1995a Origin structures and systems of precedence in the comparative study of Austronesian societies. In P.J.K. Li, Cheng-hwa Tsang, Ying-kuei Huang, Dah-an Ho and Chiu-yu Tseng (eds), Austronesian studies relating to Taiwan, pp.27-57. Taipei: Symposium Series of the Institute of History \& Philology: Academia Sinica 3.

1995b Austronesian societies and their transformations. In Peter Bellwood, James J. Fox and Darrell Tryon (eds), The Austronesians: historical \& comparative perspectives, pp.214-228. Canberra: Department of Anthropology, Research School of Pacific and Asian Studies, The Australian National University. Comparative Austronesian Series, ANU E Press: http://epress.anu.edu.au/.

1996 The transformation of progenitor lines of origin: patterns of precedence in eastern Indonesia. In James J. Fox and Clifford Sather (eds), Origins, ancestry and alliance: explorations in Austronesian ethnography, pp.130-153. Canberra: Department of Anthropology, Research School of Pacific and Asian Studies, The Australian National University. Comparative Austronesian Series, ANU E Press: http://epress.anu.edu.au/. 
2008 Installing the 'outsider' inside: the exploration of an epistemic Austronesian cultural theme and its social significance, Indonesia and the Malay World 36(105): 201-218.

Freeman, Derek

1981 Some reflections on the nature of Iban society. Occasional Paper. Canberra: Department of Anthropology, Reseach School of Pacific and Asian Studies, The Australian National University.

Lewis, E.D.

1996 Origin structures and precedence in the social orders of Tana 'Ai and Sikka. In James J. Fox and Clifford Sather (eds), Origins, ancestry and alliance: explorations in Austronesian ethnography, pp.161-182. Canberra: Department of Anthropology, Research School of Pacific and Asian Studies, The Australian National University. Comparative Austronesian Series, ANU E Press: http://epress.anu.edu.au/.

Matsuzawa, Kazuko

1989 The social and ritual supremacy of the first-born: Paiwan kinship and chieftainship. Unpublished PhD thesis. Syracuse, New York: Syracuse University.

McKinnon, Susan

1991 From a shattered sun: hierarchy, gender and alliance in the Tanimbar Islands. Madison: The University of Wisconsin Press.

1995 Houses and hierarchy: a view from a South Moluccan society'. In Janet Carsten and Stephen Hugh-Jones (eds), About the house: Lévi-Strauss and beyond, pp. 170-188. Cambridge: Cambridge University Press.

Metge, Joan

1967 The Maori of New Zealand. London: Routledge and Kegan Paul.

Sather, Clifford

1996 All threads are white: Iban egalitarianism reconsidered. In James J. Fox and Clifford Sather (eds), Origins, ancestry and alliance: explorations in Austronesian ethnography, pp.72-115. Canberra: Department of Anthropology, Research School of Pacific and Asian Studies, The Australian National University. Comparative Austronesian Series, ANU E Press: http://epress.anu.edu.au/. 
Therik, Tom

2004 Wehali, the female land: traditions of a Timorese ritual centre. Canberra: Department of Anthropology, Research School of Pacific and Asian Studies, The Australian National University in association with Pandanus Books.

\section{ENDNOTES}

1 There are many features of this Tanimbarese marriage exchange network that call for further investigation. The relational terminology of the Tanimbarese of Fordata Island is one of symmetric, rather than asymmetric alliance; its institutions, at all but the highest level, operate to promote and extend asymmetric marriage. It would be most interesting, if this network could be formally modelled to better understand its inner dynamics.

2 The full genealogy of Masa-Huk can be found in Fox 1971:51-52.

3 The narrative ends with the final observation to explain why the domain is known both by the name, Pada, and the name, Termanu:

In the time of Lord Tolamanu Amalo, a descendant of Ma Bulan, the Company asked Tolamanu: 'What is the name of your domain?' So Tolamanu said: 'It is called Tolamanu in recognition of my name.' So it was called Termanu but the name Pada did not disappear. The domain is called by both names, Pada and Termanu, to the present time. 